\title{
Assessing the role of mass media in information mitigation on COVID-19 pandemic issues in Indonesia: A discourse analysis on $K O M P A S$ daily newspaper
}

\author{
Megasari Noer Fatanti* \\ Universitas Negeri Malang, Malang City, Indonesia \\ Choiria Anggraini \\ Telkom University, Bandung City, Indonesia
}

\begin{abstract}
The spread of the COVID-19 outbreak caused by the novel coronavirus across continents has also garnered Indonesian media attention from a variety of perspectives. As a national newspaper, KOMPAS has regularly reported on the coronavirus that has spread from Wuhan, China since January 2020. The aim of this paper is to investigate where the media places responsibility for COVID-19 in Indonesia. KOMPAS newspaper articles have been sampled from 12 January to 18 May 2020. Investigators collected 30 news samples between January and May of 2020. The news samples were then categorized into three big themes, namely (1) prevention strategies; (2) outbreak management; and (3) the communication strategy for further analysis using reality construction theory to determine how KOMPAS narrated the COVID-19 outbreak that happened in Indonesia. As preliminary findings, the role of the media is very crucial to oversee the government to make optimal efforts in the detection, monitoring and management of handling COVID-19. In addition, the media plays a major role in shaping public perceptions of the health risks of COVID19. However, on the other hand, some people get fed up with news related COVID-19. This is because the viewpoint of writing presented in the media considered it haunting and put pressure on the public.
\end{abstract}

Keywords: crisis communication, COVID-19, KOMPAS, mass media, media discourse

\section{INTRODUCTION}

For the first time in the past year, health issues has become the dominant narrative in the national print media coverage. The spread of the COVID-19 outbreak cross continents has also attracted media attention, particularly in Indonesia. Most of national media take COVID-19 as main news. Republika, for example, printed as much as 42.3 percent of COVID-19 news raised in February. This theme also become the main discussion for other media, such as KOMPAS and Media Indonesia (MI) (Kompas 2020). Print media in Indonesia use various approaches in reporting each stage of the development of COVID-19. Educational efforts were also carried out to ward off false information and calm the public regarding the COVID-19 outbreak. In this case, the efforts of several print media to provide comforting information for the public show that the mass media continue to function as information and educational media as mandated by "Constitutional Law Number 40 Year 1999 about Press" of 1999. This needs to be done so that the public can absorb complete information about COVID-19 amid the flood of information on social media. This article aims

*Corresponding author: megasari.fatanti.fis@um.ac.id 
to find out the narrative of the news about COVID-19 in the KOMPAS newspaper as a form of mitigating the health crisis during the pandemic.

\section{LITERATURE REVIEW}

\subsection{Risk communication in health issue}

According to (Coombs 2014) a crisis is defined as the perception of unpredictable events and has the potential to seriously threaten stakeholder expectations, and can affect the performance of an organization and produce negative output. Meanwhile, crisis communication is the collection, processing and dissemination of information needed to handle a crisis situation. Crisis communication is the most important process of managing a complex organization. Most of the crisis communication literature still discusses organizational or corporate crises with a top-down model and very limited discussion relating to interactive crisis communication during disaster conditions (Coombs 2014; Fearn-Banks 2016; Fronz 2011; Lerbinger 2012). Furthermore, the crisis communication literature is very much dominated by Western approaches which are sometimes not fully applicable in Indonesia due to different levels of disaster awareness, various levels of technology adoption, complicated bureaucratic processes, and the high influence of local culture in daily communication behavior (Gultom \& Joyce 2014). Several studies that discuss crisis communication strategies in dealing with health issues or pandemics still focus on the use of media as a channel for delivering messages, not many have systematically discussed the stages of comprehensive crisis communication (Reynolds \& Seeger, 2005; Reynolds \& Quinn 2008).

\subsection{Roles of mass media}

Mass media or mass communication has a strategic role and function in dealing with various problems that arise in human life. Mass media is a form of communication aimed at a number of general audiences, in large numbers, and through print or electronic media, and with this form of communication, the information disseminated can reach various elements of society. Mass media is a powerful source of control, management, and innovation tools in society that can be utilized as a substitute for other strengths or resources (McQuail 1987; Rosenberry \&Vicker 2017). In pandemic conditions, the mass media has an important role in conveying accurate information about the spread of the virus to increase public awareness to live clean in order to avoid transmission of the COVID-19 virus. The presence of mass media, especially newspapers and television is also a strategy to clarify the large amount of false information that has been spread through social media related to COVID-19.

\section{METHODS}

To develop a comprehensive description of how the mass media in Indonesia are reporting on the COVID-19 pandemic, we chose a qualitative research approach. The research method used is discourse analysis on COVID-19 news published by the KOMPAS newspaper in the January to May 2020 period. Document analysis has a similar analogy to discourse analysis, therefore we use documents in the form of news to build public health realities in context of social media in Indonesia (Zeegers \& Barron 2015). The research analysis unit consists of 30 news items classified into three themes, namely: prevention strategies, health crisis management and communication strategies. Based on the interpretation of the data generated from this research, it was found that KOMPAS had a high intensity in the prevention strategy phase and the lack of available personal protective equipment (PPE) for health workers, but decreased slightly when the government's narrative regarding the crisis seemed to underestimate what was conveyed by the media. From February to March, KOMPAS coverage was more focused on economic issues as an impact from 
Table 1.

\begin{tabular}{|c|c|c|}
\hline No & Main Themes & Sub-Themes \\
\hline 1. & Prevention Strategy & $\begin{array}{l}\text { 1.1 Building awareness in mass media } \\
\text { 1.2 Screening of possible cases } \\
\text { 1.3 Quarantine of possible cases } \\
\text { 1.4 Building task force team for COVID-19 } \\
\text { 1.5 Development of COVID-19 barrier policies } \\
\text { 1.6 Collaboration with another country and organization }\end{array}$ \\
\hline 2. & Outbreak Management & $\begin{array}{l}\text { 2.1 Isolation \& treatment of COVID-19 cases } \\
\text { 2.2 Test \& contact tracing of suspected COVID-19 case } \\
\text { 2.3 Procurement of personal protective equipment }\end{array}$ \\
\hline 3. & Communication Strategy & $\begin{array}{l}\text { 3.1 To engage the population } \\
\text { 3.2 To control the outbreak } \\
\text { 3.3 To prevent fake news (conspiracy etc.) } \\
\text { 3.4 Building public optimism }\end{array}$ \\
\hline
\end{tabular}

Source: Author, 2020

COVID-19 pandemic. Final review results in April, KOMPAS has again highlighted government policies in tackling COVID-19 transmission, such as for example urging the government to carry out the $3 \mathrm{M}$ movement (tracing, testing, treatment).

\section{RESULT AND ANALYSIS}

\subsection{COVID-19 discourse on KOMPAS daily newspaper}

Through out the beginning of 2020 to mid-February, the coronavirus attack was the central theme of coverage in six national newspapers in Indonesia (Kompas 2020). Public vigilance against the attack of the coronavirus, which is known as a deadly virus, is in line with the agenda of setting newspapers which intensively discusses it as headlines on page one. Based on the results of the content analysis of 30 headlines from the KOMPAS newspaper for the period of January to May of 2020, it shows the firmness of the news regarding the increasingly rapid spread of the virus and the weak management of the Indonesian government's crisis. The headline narrative for the January to February period emphasizes that Indonesia has entered a critical period for the COVID-19 pandemic. In addition, newspapers are also critical of the handling of COVID-19 by the government, for example in terms of providing means of personal protective equipment (PPE) and masks which are increasingly depleting for health workers. On the other hand, the newspapers appreciated the efforts of mutual cooperation from the community independently of the solidarity efforts of providing personal protective equipment (PPE) for medical personnel. Meanwhile, from March to May, news stories began to develop discussing the role of health workers in dealing with the pandemic and briefly reviewing the development of the COVID-19 vaccine in several countries.

\subsection{COVID-19 newsmaker in mass media}

For almost three months, the COVID-19 outbreak was reported on page one in six national newspapers, a number of figures were recorded by newsmakers. The newsmaker is a party in the news and is in the media spotlight because they are the ones quoted. President Joko Widodo is the newsmaker with the most quoted statements by six national newspapers regarding COVID-19. The next newsmaker is Achmad Yurianto, the government spokesman for the handling of COVID-19. The role of Achmad Yurianto, explaining to the press regarding the development of the handling of COVID-19, places him as an official source of information or a reference that is forwarded by the press to the news. If traced further, the attributes of the resource persons will also focus on the President and 
ministers or ministerial staff related to handling COVID-19. Next, community members rank next as sources who are consistently consulted by newspapers for their opinions or statements.

\section{SUMMARY}

Preventive efforts against COVID-19 are currently the joint responsibility of the government and society. No matter how strong the instructions from the government to limit themselves, even to the level of quarantine, without the active role of citizens to work together to protect themselves by maintaining health, efforts to suppress the spread of COVID-19 will be in vain. Effective public communication in times of crisis does not only rely on digital media, but must optimize the combination of digital and conventional media. For example, the use of traditional or local communication channels, mass media, social media, chat applications and creative networks (Ramadani 2019). It also relies on opinion leaders (opinion leaders, influencers), educational institutions (campuses, schools), religious, social, local bureaucracy (RT, RW), and so on. The use of communication channels between individuals and groups, as well as direct communication interventions in the field, are needed in order to absorb community responses and accelerate the delivery of information from the government. In reference to Kriyantono and Sa'diyah, 2018, one of the reasons for the failure of government communication in dealing with crises is the lack of understanding of communicators in managing communication and public culture.

\section{REFERENCES}

'Constitutional Law Number 40 Year 1999 about Press' (1999).

Coombs, W. T. (2014) Ongoing crisis communication: Planning, managing, and responding. Sage Publications. Fearn-Banks, K. (2016) Crisis communications: A casebook approach. Routledge.

Fronz, C. (2011) Strategic management in crisis communication: A multinational approach. Diplomica Verlag.

Gultom, D. I. and Joyce, Z. (2014) 'Crisis communication capacity for disaster resilience: Community participation of information providing and verifying in Indonesian volcanic eruption', in ANZTSR 2014.

Kriyantono, R. and Sa'diyah, H. (2018) 'Kearifan Lokal dan Strategi Komunikasi Public Relations di BUMN dan Perusahaan Swasta', Jurnal ILMU KOMUNIKASI. doi: 10.24002/jik.v15i2.1480.

Lerbinger, O. (2012) The crisis manager: Facing disasters, conflicts, and failures. Routledge.

McQuail, D. (1987) Mass communication theory: An introduction. Sage Publications, Inc.

Ramadani, T. (2019) 'The Implementation of Public Communication Management Policy at Ministry of Energy and Mineral Resources', Jurnal Borneo Administrator. doi: 10.24258/jba.v15i1.369.

Reynolds, B. and Quinn, S. C. (2008) 'Effective communication during an influenza pandemic: the value of using a crisis and emergency risk communication framework', Health promotion practice, 9(4_suppl), pp. 13S-17S.

Reynolds, B. and Seeger, M. W. (2005) 'Crisis and emergency risk communication as an integrative model', Journal of Health Communication. doi: 10.1080/10810730590904571.

Rosenberry, J. and Vicker, L. A. (2017) Applied mass communication theory: A guide for media practitioners. Routledge.

Zeegers, M. and Barron, D. (2015) Milestone Moments in Getting your PhD in Qualitative Research, Milestone Moments in Getting your PhD in Qualitative Research. doi: 10.1016/C2014-0-02299-X. 